\title{
Reasoning Guide in Perinatal Palliative Care
}

\author{
Rufo $\mathrm{R}^{*}$ and Boccarato A \\ Department of Neonatology, Pereira Rossell Hospital, Uruguay \\ Submission: May 24, 2019; Published: June 07, 2019 \\ *Corresponding author: Rufo R, Department of Neonatology, Pereira Rossell Hospital, Uruguay
}

Keywords: Neonatology; Disabling; Diseases; Sense; Palliative care

\section{Introduction}

"Perinatal palliative care provides a bio-psycho-social and spiritual approach to sustain and improve the quality of life of patients and families facing the problems associated with disabling or life/threatening diseases in a broad sense, even when disease or/and death occur later on" [1]. An educational guide is essential and necessary. The reason of this work is to search reference educational tools to reflection about this topic.

\section{Goal}

We propose a Reasoning Guide in Perinatal and Neonatal Palliative Care as an educational instrument aimed at enabling health staff at different levels to identify possible scenarios and to coordinate an immediate interdisciplinary approach.

\section{Method}

It is a bibliography review guided by the problem to be resolved and selected instruments, with authorized adaptation, and used our own work and the educational experience resulting from its application combined with the study of clinical cases in pre and post degree modules. The authors have no conflicts of interest.

\section{Results}

\section{Reasoning Guide in Perinatal Palliative Care}

\section{A -Step 1:}

a) Questions

Can this fetus or newborn baby be the subject of perinatal palliative care? [2].

\section{b) Educational tools}

It is applicate in case of doubts the Modified Necpal surprise question [3]: Surprise question 1 with Negative answer: SQ (1) "Would I be surprised if this fetus or newborn got seriously ill or died in the short term?" If the answer is "No, I wouldn't", it can receive PPC. If the answer is "Yes, I would ", ask..."

Surprise question 2 with Positive answer. SQ (2): "Would I be surprised if this fetus or newborn had a good quality of life? "If the answer is "Yes, I would "it should receive PPC.

\section{B- Step 2:}

\section{a) Questions}

What is the fetal or newborn disease or condition that threatens or limits the life?

\section{b) Educational tools}

i. Prenatal: Consider classification with the diagnosis and prognosis degree of certainty [4]. Based in our experience we also consider the degree of organ or system dysfunction.

ii. Postnatal: Consider the classification of the Association for Children with Life Threatening Conditions and their families (ACT) [5].

\section{C-Step 3:}

\section{a) Questions}

What stage in life is it in? What stage in the course of the disease is it in? Do you recognize an inflection point?

\section{b) Educational tools}

i. Prenatal: Evaluation of the maternal-fetal state and intrauterine disease progression [4].

ii. Postnatal Life Stage: It is useful the Gherardi classification modified by Bernada M [6].

iii. Course of Postnatal Disease: Lyn's disease trajectory curves modified by Judes J [7]. 
Recognize an Inflection Point: It is a point where the course of the disease change in an irreversible way [8].

\section{D- Step 4:}

\section{a) Questions}

What are the needs and problems of patient, family and staff?

\section{b) Educational tools}

i. Prenatal problems: It result of evaluation of the maternal-fetal state and intrauterine disease progression.

ii. Postnatal problems: consider the symptoms control specially.

To needs of family approach can be useful the questionnaire based on work of our own's [8].

To assess the needs of the staff, consider meetings to reflecting about the difficulties of the case and how they feel about during the process.

\section{E -Step 5:}

\section{a) Questions}

What would the treatment goals be at this stage?

\section{b) Educational tools}

i. Prenatal: It is necessary to prepare scenarios for birth and know the wishes of the family [9].

ii. Postnatal: Concepts of treatment goals, according to stage of disease, could be predominantly curative, predominantly palliative, focused on life quality or end of life care and bereavement $[9,10]$.

\section{F- Step 6:}

\section{a) Questions}

Are advance directives appropriate? If so, which ones?

\section{b) Educational tools}

The decision-making process is the most important. It must include ethics aspects. It is included the Decision Method in Clinical Ethics of Beca JP [13]. In summary this method analyses the scientific information, if it is possible curative treatment or not, what the family known wat they want, their values and identify ethic problems to resolve.

In our experience first the team must do a meeting to decide and justified wat treatment are indicated o not indicated or contraindicated based in the best practice and the best interest of patient and then make the process of communication with the family [12].

\section{G- Step 7:}

\section{a) Questions}

What would the approach strategy be like?

\section{b) Educational tools}

A comprehensive approach should be planned based on the information obtain with the previous steps.

\section{Conclusion}

We propose the use of an educational guide to approach to perinatal palliative care. It was discussed in workshops with both pre and post graduated levels with the necessary adjustments to the level of the participants: it results easy to understand and to put into practice. It would be useful to organize local and regional workshops to unify the use of a reasoning guide in perinatal and neonatal palliative care and learn from all the different specializations.

\section{References}

1. Rufo R, Ettlin G, Boccarato A, Morales E, Hoppe A, et al. (2013) Perinatal Palliative Care: three years 'experience in a maternity ward. Work presented in XXIX Uruguayan Congress of Pediatrics 15th to 18 the October 2013, LATU, Montevideo, Uruguay, quoted in: De Pena L, et al. Analysis and reflections, from a bioethical perspective in psychiatric clinical practice, resulting from a case. Urug Psychiat 78(1): 31-41.

2. Bernada M (2012) Cuidados paliativos pediatricos, in Archivos de Pediatria. Uruguay 83(3): 203-210.

3. (2016) Necpal Instrument-CCOMS-ICO@ 3.0.

4. Bhatia J (2006) Palliative care in the fetus and newborn. Journal of Perinatology 26: S24-S26.

5. Himelstein B, Hilden J, Morstad A, Weissman D (2004) Pediatric Palliative Care. N Engl J Med 350: 1752-1762.

6. Gherardi C (2012) Ethics at the end of life. Module III Programme of Bioethics Permanent Education. UNESCO Bioethics net quoted in Bernada $\mathrm{M}$ et al. Pediatric Palliative Care in Pediatric Files, Uruguay 83(3): 203-210.

7. Javier Jude's (2004) Changes in J Lynn's curves.

8. Ortiz L, Martino R (2016) Palliative approach in Pediatrics. Pediatrics XX(2): 131.e1-131.e7

9. Rufo R, Boccarato A, Lujambio M (2018) Needs of Families in Perinatal Palliative Care and Proposal for a Model Training Questionnaire. Journal of Anesthesia and Patient Care 2(1): 2456-5490.

10. Munson D, Leuthner S (2007) Palliative Care for Families having a fetus diagnosed with a life-threatening disease. Pediatr Clin N Am 54: 787798.

11. Guide of Clinical Practice in Palliative Care.

12. Beca JP (2012) Decision Method in Clinical Ethics. In: Beca JP, Astete C, Mediterráneo (Eds.), Chile. Clinical Bioethics 17: 232-243. 
(C) (i) This work is licensed under Creative Commons Attribution 4.0 License DOI: 10.19080/JAICM.2019.09.555753
Your next submission with Juniper Publishers will reach you the below assets

- Quality Editorial service

- Swift Peer Review

- Reprints availability

- E-prints Service

- Manuscript Podcast for convenient understanding

- Global attainment for your research

- Manuscript accessibility in different formats

( Pdf, E-pub, Full Text, Audio)

- Unceasing customer service

Track the below URL for one-step submission https://juniperpublishers.com/online-submission.php 